\title{
Compromised Rat Testicular Antioxidant Defence System by Hypothyroidism before Puberty
}

\author{
Dipak K. Sahoo ${ }^{1,2}$ and Anita Roy ${ }^{1}$ \\ ${ }^{1}$ Departments of Zoology and Biotechnology, Utkal University, Bhubaneswar, 751004 Orissa, India \\ ${ }^{2}$ KTRDC, College of Agriculture, University of Kentucky, Lexington, KY 40546-0236, USA
}

Correspondence should be addressed to Dipak K. Sahoo, dipak_sahoo11@rediffmail.com

Received 25 July 2011; Accepted 10 October 2011

Academic Editor: Daniela Jezova

Copyright ( 2012 D. K. Sahoo and A. Roy. This is an open access article distributed under the Creative Commons Attribution License, which permits unrestricted use, distribution, and reproduction in any medium, provided the original work is properly cited.

\begin{abstract}
Altered thyroid function during early stages of development is known to affect adversely testicular growth, physiology, and antioxidant defence status at adulthood. The objective of the present study is to investigate the modulation of antioxidant defence status in neonatal persistent hypothyroid rats before their sexual maturation and also to identify the specific testicular cell populations vulnerable to degeneration during neonatal hypothyroidism in immature rats. Hypothyroidism was induced in neonates by feeding the lactating mother with $0.05 \%$ 6-n-propyl-2-thiouracil (PTU) through the drinking water. From the day of parturition till weaning (25 day postpartum), the pups received PTU through mother's milk (or) drinking water and then directly from drinking water containing PTU for the remaining period of experimentation. On the 31st day postpartum, the animals were sacrificed for the study. An altered antioxidant defence system marked by elevated SOD, CAT, and GR activities, with decreased GPx and GST activities were observed along with increased protein carbonylation, disturbed redox status in hypothyroid immature rat testis. This compromised testicular antioxidant status might have contributed to poor growth and development by affecting the spermatogenesis and steroidogenesis in rats before puberty as indicated by reduced germ cell number, complete absence of round spermatids, decreased seminiferous tubule diameter, and decreased testosterone level.
\end{abstract}

\section{Introduction}

Most vertebrates are unable to grow and reach their normal adult form without the thyroid hormone $[1,2]$. The testis was considered to be a thyroid hormone unresponsive tissue [3]. However, various subsequent studies revealed that thyroid hormone plays a key role in rat testis development [4-7]. Mammalian testis is a target of thyroid hormone action and altered thyroid function which is known to affect testicular functions $[8,9]$.

Thyroid hormone is well known as a physiological modulator of oxidative stress $[10,11]$. Previous studies on the role of thyroid hormone in testis are mainly focused on histological and physiological aspects resulting into reproductive failure $[6,8,12-14]$. Thyroid hormone exerts major influences on the developing testes [15]. Altered thyroid function during early stages of development and maturation may adversely affect testicular growth and physiology [7-9]; particularly the Sertoli cells, which play a major role in spermatogenesis and are the main cell type in the testis which expresses $T_{3}$ receptors [16]. Studies indicate that there is an increase in $\mathrm{T}_{3}$ receptors in the neonates [5]. It is well established that the formation of normal numbers of Sertoli cells is a key factor in determining testis size, germ cell numbers per testis, and sperm production rate in adulthood in a range of mammals, including humans [17].

In our earlier reports, it was demonstrated that experimentally hypothyroidism modulates several oxidative stress and antioxidant defence parameters in mitochondria and postmitochondrial fractions in adult rat testis $[18,19]$. We also reported about the effects of transient and persistent hypothyroidism on testicular antioxidant defence system in mature rats to know the role of hypothyroidism-induced oxidative stress in testicular development and maturation [7]. 
However, information about the role of deprivation of thyroid hormone in early developmental growth and function of testis in relation to antioxidant status in immature rats is inadequate. In rat, the onset of spermatogenesis occurs around 5 days of age. Spermatogenesis reaches the pachytene stage at 20 days of age. At 25 days of age, round spermatids appear, and at the age of 50 days, mature spermatozoa are released into seminiferous tubular lumen [20,21]. Fetal type Leydig cells disappear soon after birth (during first 2 weeks after birth) and are replaced by adult type Leydig cells [22, 23]. Sertoli cell proliferation reaches its maximum level just before birth and ceases by the age of 3 weeks [24]. Hence, four weeks or around 30 days of age, testis is undergoing critical stages of development and thyroid hormone is playing a key role during this stage. In our earlier studies, it was reported that transient hypothyroidism (from day 1 of neonatal age till day 30) modulated testicular antioxidant defence status as well as functions in adult stage [7]. Moreover, it was also shown that germ cells in these rats were under oxidative stress and had poor antioxidant defence system [25]. So, it is interesting to know about the testicular antioxidant defence status and oxidative stress parameters along with testicular physiology at the 30 days of age, that is, before puberty.

The objective of the present study is to investigate the modulation of antioxidant defence status in neonatal persistent hypothyroid rats before their sexual maturation. In addition, we have tried to identify the specific cell populations in testes vulnerable to degeneration during neonatal hypothyroidism in immature rats.

\section{Materials and Methods}

2.1. Animals and Treatments. Male pups obtained from breeding were made hypothyroid from day 1 of neonatal age till day 30 of postnatal age. Hypothyroidism was induced in neonates by feeding the lactating mother with $0.05 \%$ 6-n-propyl-2-thiouracil (PTU) through the drinking water $[7,18,25]$. From the day of parturition till weaning (25 day postpartum), the pups received PTU through mother's milk (or) drinking water and then directly from drinking water containing $0.05 \%$ PTU for the remaining period of experimentation. Adult male Wistar rats (Rattus norvegicus) were divided into two groups containing 15 animals each. Group-I rats served as control for Group II rats. Group-II rats were treated with PTU from day 1 postpartum to day 30 postpartum. Animal care, maintenance, and experiments were conducted under the supervision of the Institutional Animal Ethics Committee (IAEC) regulated by the Committee for the Purpose of Control and Supervision of Experiments on Animals (CPCSEA), Government of India.

2.2. Sample Preparation and Hormone Estimations. On the 31st day postpartum, body weight of animals in Group-I and II was recorded; the animals were sacrificed by decapitation, trunk blood was collected and allowed to clot and then centrifuged to obtain sera. The serum levels of total $\mathrm{T}_{3}, \mathrm{~T}_{4}$,
TSH, and testosterone were measured by using ELISA kits (Monobind, Inc., Costa Mesa, CA, USA, and Equipar diagnostici, Italy). Testes and accessory sex organs, that is, seminal vesicle, ventral prostate and epididymis were removed, cleaned in cold $0.15 \mathrm{~mol} / \mathrm{L} \mathrm{NaCl}$ (normal saline), pat dried, and weighed. Testes were kept at $-80^{\circ} \mathrm{C}$ till further use. Testes from three animals were pooled to one sample and five such samples were taken for the study.

\subsection{Isolation of Mitochondrial and Postmitochondrial Frac-} tions and Biochemical Analyses. The whole procedure of tissue processing was done as described earlier by Sahoo et al. (2008) [7]. In brief, a 20\% (w/v) homogenate of testis was prepared in $50 \mathrm{mM}$ phosphate buffer, $\mathrm{PH} 7.4$, containing $0.25 \mathrm{M}$ sucrose. The crude homogenate $(\mathrm{CH})$ was centrifuged at $600 \mathrm{~g}$ for $10 \mathrm{~min}$ to precipitate nuclei and other cellular debris. The resulted supernatant was again centrifuged at 10,000 g for $20 \mathrm{~min}$ to separate mitochondria. The supernatant obtained was the postmitochondrial fraction (PMF). The mitochondrial pellet was washed thrice in $50 \mathrm{mM}$ phosphate buffer, $\mathrm{pH} 7.4$ (10,000 g for $5 \mathrm{~min}$ each), and finally suspended in the same buffer to obtain mitochondrial fraction (MF). For lipid peroxidation (LPx), tissue samples were processed as described above except using the buffer without sucrose. Protein content of samples was estimated using bovine serum albumin as standard [26].

2.4. Oxidative Damages to Lipids and Proteins. LPx was measured in $\mathrm{CH}$ and MF by monitoring the formation of thiobarbituric acid-reactive substances (TBARSs) following Ohkawa et al. (1979) [27]. The assay was performed in presence of $0.02 \%(\mathrm{w} / \mathrm{v})$ butylated hydroxytoluene to suppress artefactual peroxidation during heating. Malondialdehyde (MDA) was used as the standard and TBARS were expressed in terms of MDA equivalents as nmol TBARS formed/mg protein. Protein carbonyl (PC) content was estimated in testicular $\mathrm{CH}, \mathrm{MF}$, and PMF following Levine et al. (1990) [28] and was expressed as nmol/mg protein.

For measuring protein-SH content, PMF and MF samples were first precipitated in ice-cold 5\% trichloroacetic acid (TCA) containing $0.01 \mathrm{M} \mathrm{HCl}$ and centrifuged at $1000 \times \mathrm{g}$ for $15 \mathrm{~min}$. Protein precipitates dissolved in $8 \mathrm{M}$ guanidine hydrochloride were then used to measure thiol content and presented as $\mu \mathrm{mol} / \mathrm{mg}$ protein $[29,30]$.

\subsection{Reduced Glutathione (GSH), Oxidized Glutathione} (GSSG), and $\mathrm{H}_{2} \mathrm{O}_{2}$ Content. Total glutathione content was measured in the supernatant of TCA-precipitated testicular PMF and MF samples by enzymatic recycling procedure and GSSG was measured after masking GSH with 2-vinylpyridine $[31,32]$. GSH content was obtained from difference between these two values. Only GSH plus twice the GSSG levels were denoted as total GSH equivalents [7]. Total GSH equivalents, GSH and GSSG contents were expressed as nmol/g tissue. Hydrogen peroxide $\left(\mathrm{H}_{2} \mathrm{O}_{2}\right)$ content was determined in testicular PMF and MF following horseradish peroxidasedependent oxidation of phenol red [33]. $\mathrm{H}_{2} \mathrm{O}_{2}$ content was expressed as $\mathrm{nmol} / \mathrm{mg}$ protein in testicular PMF or MF. 
TABLE 1: Effect of neonatal PTU treatment on bodyweight $(\mathrm{g})$ of animals. Data are expressed as mean \pm S.D. of 5 observations and subjected to unpaired Student's $t$-test. Statistical significance was accepted at $P<0.05$. Control and hypothyroid groups were found to differ significantly at $P<0.05$ as represented by superscripts of different letters. Group-I (control): 30 -day-old control rats; Group-II (hypothyroid): 30-day-old rats with PTU treatment from day 1 postpartum to day 30 postpartum.

\begin{tabular}{|c|c|c|c|}
\hline & & Group-I (control) & Group-II (hypothyroid) \\
\hline \multirow{2}{*}{ Bodyweight (g) } & Initial (on date of birth) & $6.37 \pm 0.28^{\mathrm{a}}$ & $6.69 \pm 0.44^{\mathrm{a}}$ \\
\hline & Final (on date of sacrifice) & $55.00 \pm 6.85^{\mathrm{a}}$ & $28.00 \pm 4.47^{\mathrm{b}}$ \\
\hline Weight gain (g) & & $48.63 \pm 6.68^{\mathrm{a}}$ & $21.31 \pm 4.61^{\mathrm{b}}$ \\
\hline$\%$ Decrease in body weight from control & & $\mathrm{Nil}^{\mathrm{a}}$ & $42.42 \pm 9.20^{\mathrm{b}}$ \\
\hline
\end{tabular}

TABLE 2: Effect of neonatal PTU treatment on testis and accessory sex organs (g/100 g body weight). Data are expressed as mean \pm S.D. of 5 observations and subjected to unpaired Student's $t$-test. Statistical significance was accepted at $P<0.05$. Control and hypothyroid groups were found to differ significantly at $P<0.05$ as represented by superscripts of different letters. Group-I (control): 30 day old control rats; Group-II (hypothyroid): 30-day-old rats with PTU treatment from day 1 postpartum to day 30 postpartum.

\begin{tabular}{lccc}
\hline & & Group-I (control) & Group-II (hypothyroid) \\
\hline & Testis & $0.92 \pm 0.09^{\mathrm{a}}$ & $0.28 \pm 0.02^{\mathrm{b}}$ \\
Weight $(\mathrm{g} / 100 \mathrm{~g}$ body weight) & Epididymis & $0.208 \pm 0.01^{\mathrm{a}}$ & $0.207 \pm 0.02^{\mathrm{a}}$ \\
& Seminal vesicle & $0.094 \pm 0.01^{\mathrm{a}}$ & $0.059 \pm 0.005^{\mathrm{b}}$ \\
& Ventral prostate & $0.103 \pm 0.012^{\mathrm{a}}$ & $0.08 \pm 0.006^{\mathrm{b}}$ \\
\hline
\end{tabular}

2.6. Antioxidant Enzyme Activities. For measuring the activity of catalase (CAT), PMF treated with ethanol $(0.17 \mathrm{M})$ and Triton X-100 (1\%) was directly used. The enzyme activity was measured following decomposition of $\mathrm{H}_{2} \mathrm{O}_{2}$ at $240 \mathrm{~nm}$ as described earlier [34] and expressed as nkat/mg protein. Superoxide dismutase (SOD) activity in PMF (for $\mathrm{Cu} / \mathrm{Zn}$ SOD) and MF (for Mn-SOD) of testis was determined following modified nitrite method [35]. One unit of enzyme activity was defined as the amount of enzyme capable of inhibiting $50 \%$ of nitrite formation under assay conditions.

Glutathione peroxidase (GPx) activity was assayed in PMF and MF by measuring oxidation rate of NADPH in presence of hydroperoxide, GSH, and glutathione reductase (GR) [19, 36]. Total and selenium-dependent GPx activities were estimated by using cumene and tert-butyl hydroperoxides, respectively. The difference between total glutathione peroxidase and selenium-dependent glutathione peroxidase (Se-D-GPx) activities represents the seleniumindependent glutathione peroxidase (Se-I-GPx) activity [19, 37]. Glutathione reductase (GR) activity in testicular PMF and MF was assayed by measuring oxidation rate of NADPH in presence of GSSG [38]. In testicular PMF and MF, glutathione-S-transferase (GST) activity was measured following change in absorbance of the conjugated product of GSH and 1-chloro, 2, 4-dinitrobenzene (CDNB) at $340 \mathrm{~nm}$ [39]. GPx, GR, and GST enzyme activities were expressed as nkat/mg protein.

2.7. Glucose-6-phosphate Dehydrogenase. Glucose-6-phosphate dehydrogenase (G6PD) activity was assayed in PMF by measuring NADPH formation from glucose-6-phosphate along with NADP [40] and expressed as nkat/mg protein.

2.8. Histology. Following sacrifice, testis tissues were immediately fixed for histological studies in freshly prepared sublimate formal, dehydrated in graded ethanol series, cleared in xylene, and embedded in paraffin wax. Tissues were sectioned and stained with Hematoxylin and Eosin. The sections were observed under light microscope for qualitative and quantitative characterization. Numbers of germ cells and Sertoli cells were recorded as described earlier [7].

2.9. Statistics. All data represent means \pm standard deviation and were subjected to unpaired Student's $t$-test to find out the level of significance between control and experimental rats. Minimal statistical significance was accepted at $P<0.05$.

\section{Results}

3.1. Weights of Body, Testes, and Accessory Sex Organs. The weight gain in Group-II rats on 31st day of age was almost $50 \%$ less than Group-I control rats (Table 1). The weight of testis, seminal vesicle, and ventral prostate ( $\mathrm{g} / 100 \mathrm{~g}$ body wt) decreased significantly in PTU-treated rats of Group-II (Table 2).

3.2. Serum Hormone Profile. The serum $\mathrm{T}_{3}, \mathrm{~T}_{4}$, and testosterone level decreased significantly whereas the level of TSH increased by several folds in Group-II rats in comparison to control rats in Group-I (Table 3).

3.3. Histology, Germ Cell Count. Marked decrease in seminiferous tubule diameter was observed in neonatal persistent hypothyroid 30-day-old rats (Group-II) as compared to the corresponding controls (Table 4). There was a significant decrease in spermatogonia (24\%) and spermatocytes (79\%) accompanied by complete absence of round spermatids in Group-II testis (Table 4). However, a significant increase in the Sertoli cell number in Group-II rat testis was marked (Table 4). 
TABLE 3: Effect of neonatal PTU treatment on serum total $\mathrm{T}_{3}$, total $\mathrm{T}_{4}$, testosterone levels $(\mathrm{ng} / \mathrm{mL})$, and thyroid stimulating hormone (TSH) level in $\mu \mathrm{IU} / \mathrm{mL})$. Data are expressed as mean \pm S.D. of 5 observations and subjected to unpaired Student's $t$-test. Statistical significance was accepted at $P<0.05$. Control and hypothyroid groups were found to differ significantly at $P<0.05$ as represented by superscripts of different letters. Group-I (control): 30-day-old control rats; Group-II (hypothyroid): 30-day-old rats with PTU treatment from day 1 postpartum to day 30 postpartum.

\begin{tabular}{lcc}
\hline Serum hormones & Group-I (control) & Group-II (hypothyroid) \\
\hline Total $\mathrm{T}_{3}(\mathrm{ng} / \mathrm{mL})$ & $1.68 \pm 0.16^{\mathrm{a}}$ & $1.02 \pm 0.08^{\mathrm{b}}$ \\
Total $\mathrm{T}_{4}(\mathrm{ng} / \mathrm{mL})$ & $13.00 \pm 3.92^{\mathrm{a}}$ & $3.00 \pm 0.61^{\mathrm{b}}$ \\
$\mathrm{TSH}(\mu \mathrm{IU} / \mathrm{mL})$ & $0.12 \pm 0.027^{\mathrm{a}}$ & $1.69 \pm 0.089^{\mathrm{b}}$ \\
Testosterone $(\mathrm{ng} / \mathrm{mL})$ & $0.25 \pm 0.03^{\mathrm{a}}$ & $0.09 \pm 0.02^{\mathrm{b}}$ \\
\hline
\end{tabular}

TABLE 4: Effect of neonatal PTU treatment on germ cell count (number/tubule) and seminiferous tubule diameter (expressed in $\mu$ ) in StageVII seminiferous tubules of testes. Data are expressed as mean \pm S.D. of 5 observations from five different animals and subjected to unpaired Student's $t$-test. Each observation per animal is the mean of 30 observations. Statistical significance was accepted at $P<0.05$. Control and hypothyroid groups were found to differ significantly at $P<0.05$ as represented by superscripts of different letters. Group-I (control): 30-day-old control rats; Group-II (hypothyroid): 30-day-old rats with PTU treatment from day 1 postpartum to day 30 postpartum.

\begin{tabular}{lcc}
\hline & Group-I (control) & Group-II (hypothyroid) \\
\hline Primary spermatogonia (number/tubule) & $25.12 \pm 0.41^{\mathrm{a}}$ & $19.11 \pm 0.17^{\mathrm{b}}$ \\
Number of spermatocytes (number/tubule) & $15.77 \pm 1.65^{\mathrm{a}}$ & $3.31 \pm 0.33^{\mathrm{b}}$ \\
Round spermatids (number/tubule) & $46.50 \pm 5.02^{\mathrm{a}}$ & $\mathrm{Nil}^{\mathrm{b}}$ \\
Sertoli cell number (number/tubule) & $30.09 \pm 0.34^{\mathrm{a}}$ & $39.05 \pm 2.14^{\mathrm{b}}$ \\
Seminiferous tubule diameter $(\mu)$ & $121.13 \pm 3.98^{\mathrm{a}}$ & $89.04 \pm 3.82^{\mathrm{b}}$ \\
\hline
\end{tabular}

3.4. Oxidative Stress Parameters. The level of endogenous lipid peroxidation showed a decrease by $13.6 \%$ and $64 \%$ in crude and mitochondrial fractions, respectively, in response to 30 days persistent PTU treatment (group-II) in comparison to control (Group-I) rats (Figure 1).

A significant elevation in protein carbonyl content was recorded in the crude homogenate (by 35.6\%), mitochondrial $(78 \%)$, and postmitochondrial fraction $(22 \%)$ of testis of Group II hypothyroid rats when compared to the controls (group I, Figure 2).

Hydrogen peroxide content remained unaltered in PMF and decreased (by 15\%) in MF of Group-II PTU-treated rats (Figure 3).

3.5. Protein-SH. The protein-SH content decreased significantly by $14 \%$ and $24 \%$, respectively, in mitochondrial and postmitochondrial fractions of testis of Group-II rats (Figure 4).

3.6. Total, Oxidized, and Reduced Glutathione Contents. In mitochondrial fraction of testis of group-II, rats, total GSH equivalent, oxidized, and reduced glutathione contents and GSH to GSSG ratio declined, respectively, by 50\%, $16.7 \%$, $67 \%$, and $61 \%$ (Table 5). On the other hand, the GroupII testicular postmitochondrial total GSH equivalent and reduced glutathione contents did not alter with $23.5 \%$ decrease in GSSG activity and 27\% elevation in GSH to GSSG ratio (Table 5).

3.7. Antioxidant Enzyme Activities. The Mn-SOD activity was elevated by $20 \%$ in MF whereas $\mathrm{Cu} / \mathrm{Zn}$-SOD activity was increased by $30 \%$ in PMF of testis of Group-II rats (Figure 5).

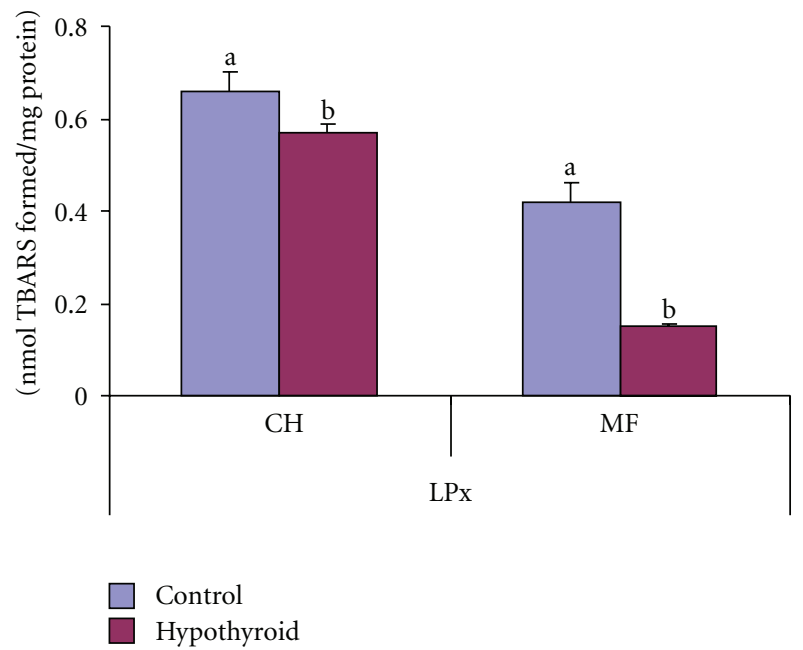

FIGURE 1: Effect of neonatal PTU treatment on lipid peroxidation (LPx; nmol TBARS formed/mg protein) in crude homogenate $(\mathrm{CH})$ and mitochondrial fraction (MF) of testes of rats. Data are expressed as mean \pm S.D. of 5 observations and subjected to unpaired Student's $t$-test. Statistical significance was accepted at $P<$ 0.05 . Control and hypothyroid groups were found to differ significantly at $P<0.05$ as represented by superscripts of different letters. Control (Group-I): 30-day-old control rats; hypothyroid (GroupII): 30-day-old rats with PTU treatment from day 1 postpartum to day 30 postpartum.

In the postmitochondrial fraction of testis, the CAT activity was increased by $83 \%$ in response to PTU treatment in Group-II rats in comparison to control rats (Group-I) (Figure 6). 
TABLe 5: Effect of neonatal PTU treatment on total, oxidized, reduced glutathione contents (nmol thiols/g tissue) of testes of rats. Data are expressed as mean \pm S.D. of 5 observations and subjected to unpaired Student's $t$-test. Statistical significance was accepted at $P<$ 0.05. Control and hypothyroid groups were found to differ significantly at $P<0.05$ as represented by superscripts of different letters. Group-I (Control): 30 day old control rats; Group-II (Hypothyroid): 30-day-old rats with PTU treatment from day 1 postpartum to day 30 postpartum; T-GSH-eq: total GSH equivalent; GSH: reduced glutathione, GSSG: oxidized glutathione.

\begin{tabular}{cccc}
\hline & & Group-I (control) & Group-II (hypothyroid) \\
\hline & T-GSH-eq (nmol thiols/g tissue) & $108.89 \pm 8.53^{\mathrm{a}}$ & $54.45 \pm 4.26^{\mathrm{b}}$ \\
MF & GSSG (nmol thiols/g tissue) & $18.59 \pm 1.53^{\mathrm{a}}$ & $15.49 \pm 1.28^{\mathrm{b}}$ \\
GSH (nmol thiols/g tissue) & $71.72 \pm 5.48^{\mathrm{a}}$ & $23.47 \pm 1.73^{\mathrm{b}}$ & $1.52 \pm 0.02^{\mathrm{b}}$ \\
\hline GSH : GSSG (nmol thiols/g tissue) & $3.86 \pm 0.04^{\mathrm{a}}$ & $1133.54 \pm 80.64^{\mathrm{a}}$ \\
PMF & T-GSH-eq (nmol thiols/g tissue) & $1227.23 \pm 96.12^{\mathrm{a}}$ & $89.43 \pm 8.21^{\mathrm{b}}$ \\
& GSSG (nmol thiols/g tissue) & $116.98 \pm 9.81^{\mathrm{a}}$ & $954.40 \pm 79.96^{\mathrm{a}}$ \\
& GSH (nmol thiols/g tissue) & $992.74 \pm 76.71^{\mathrm{a}}$ & $10.75 \pm 1.40^{\mathrm{b}}$ \\
\hline
\end{tabular}

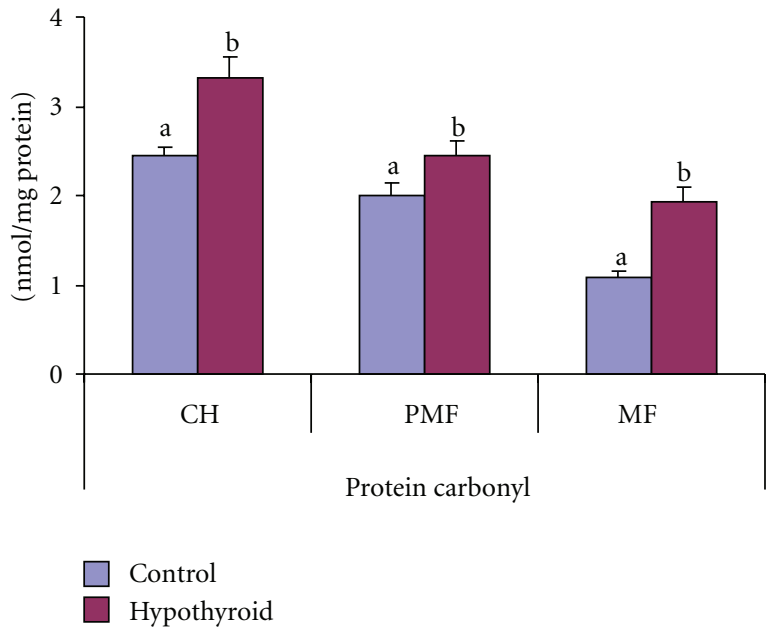

FIGURE 2: Effect of neonatal PTU treatment on protein carbonyl content (nmol/mg protein) in crude homogenate $(\mathrm{CH})$, postmitochondrial fraction (PMF), and mitochondrial fraction (MF) of testes of rats. Data are expressed as mean \pm S.D. of 5 observations and subjected to unpaired Student's $t$-test. Statistical significance was accepted at $P<0.05$. Control and hypothyroid groups were found to differ significantly at $P<0.05$ as represented by superscripts of different letters. Control (Group-I): 30-day-old control rats; hypothyroid (Group-II): 30-day-old rats with PTU treatment from day 1 postpartum to day 30 postpartum.

In Group-II rat testicular mitochondrial fraction, the GPx activities remained unaltered (Figure 7). However, in postmitochondrial fraction, total GPx and Se-I-GPx declined, respectively, by $6.7 \%$ and $22.35 \%$ with $9.5 \%$ elevation in Se-D-GPx activity (Figure 7). The GR activity increased significantly by $56 \%$ and $55 \%$, respectively, in mitochondrial and postmitochondrial fractions of testis of Group-II rats in response to PTU treatment for 30 days (Figure 8).

The GST activity decreased by $59 \%$ in mitochondrial fraction and elevated by $42 \%$ in postmitochondrial fraction of testis in response to PTU treatment in Group-II rats when compared to control rats (Group-I, Figure 9).

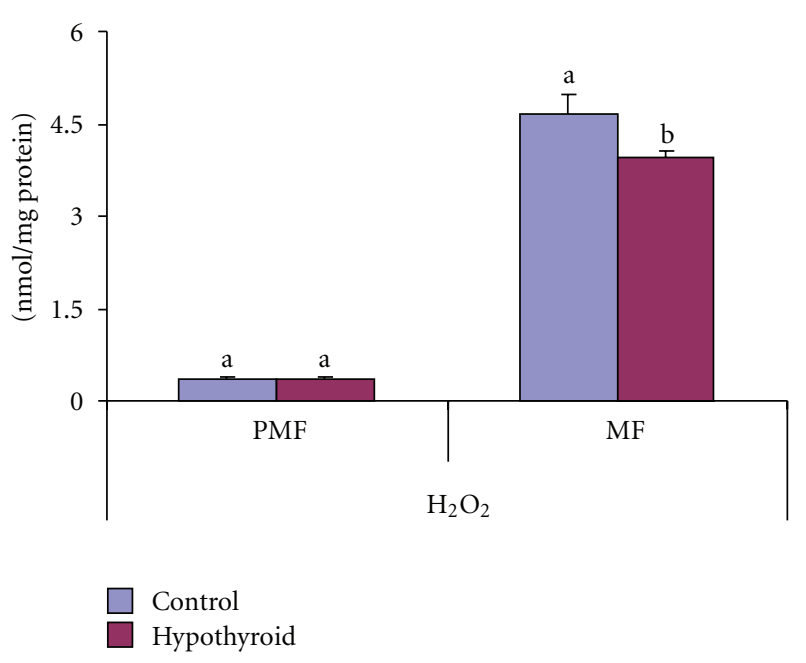

FIGURE 3: Effect of neonatal PTU treatment on hydrogen peroxide $\left(\mathrm{H}_{2} \mathrm{O}_{2} ; \mathrm{nmol} / \mathrm{mg}\right.$ protein) in postmitochondrial fraction (PMF) and mitochondrial fraction (MF) of testes of rats. Data are expressed as mean \pm S.D. of 5 observations and subjected to unpaired Student's $t$-test. Statistical significance was accepted at $P<0.05$. Control and hypothyroid groups were found to differ significantly at $P<0.05$ as represented by superscripts of different letters. Control (Group-I): 30-day-old control rats; hypothyroid (GroupII): 30-day-old rats with PTU treatment from day 1 postpartum to day 30 postpartum.

3.8. Glucose-6-phosphate Dehydrogenase (G6PD). An increase in enzyme activity in post mitochondrial fraction of testis was recorded in Group-II rats by 73\% (Figure 10).

\section{Discussion}

Thyroid hormones are reported to play a critical role in growth, differentiation, maturation, and metabolism in vertebrates [41]. Essential role of thyroid hormone in male sexual maturation, and reproduction was reported earlier [4, $6,42]$. Both hyperthyroidism and hypothyroidism states alter testicular antioxidant defence parameters in adult 


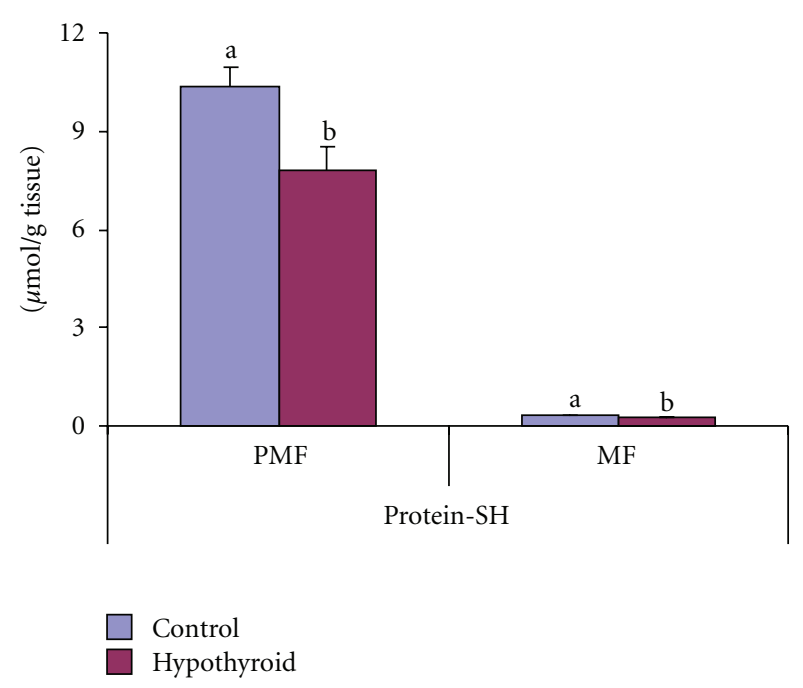

FIgUre 4: Effect of neonatal PTU treatment on protein-SH content ( $\mu \mathrm{mol} / \mathrm{g}$ tissue) in postmitochondrial fraction (PMF) and mitochondrial fraction (MF) of testes of rats. Data are expressed as mean \pm S.D. of 5 observations and subjected to unpaired Student's $t$-test. Statistical significance was accepted at $P<0.05$. Control and hypothyroid groups were found to differ significantly at $P<$ 0.05 as represented by superscripts of different letters. Control (Group-I): 30-day-old control rats; hypothyroid (Group-II): 30day-old rats with PTU treatment from day 1 postpartum to day 30 postpartum.

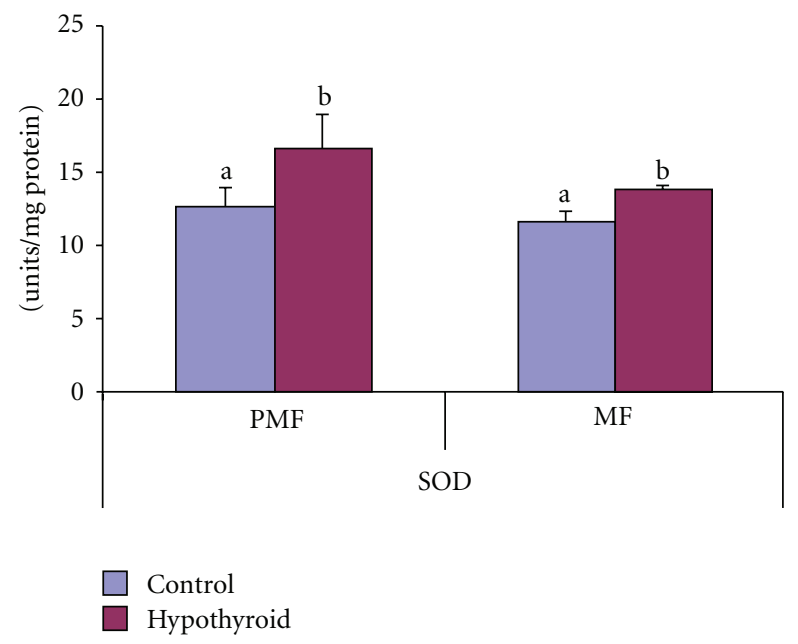

FIGURE 5: Effect of neonatal PTU treatment on superoxide dismutase activity (SOD; units/mg protein) in postmitochondrial fraction (PMF) and mitochondrial fraction (MF) of testes of rats. Data are expressed as mean \pm S.D. of 5 observations and subjected to unpaired Student's $t$-test. Statistical significance was accepted at $P<$ 0.05 . Control and hypothyroid groups were found to differ significantly at $P<0.05$ as represented by superscripts of different letters. Control (Group-I): 30-day-old control rats; hypothyroid (GroupII): 30 -day-old rats with PTU treatment from day 1 postpartum to day 30 postpartum.

rats $[7,18,19,25,43-45]$. However, the effects of persistent hypothyroidism on neonatal rats before their puberty need

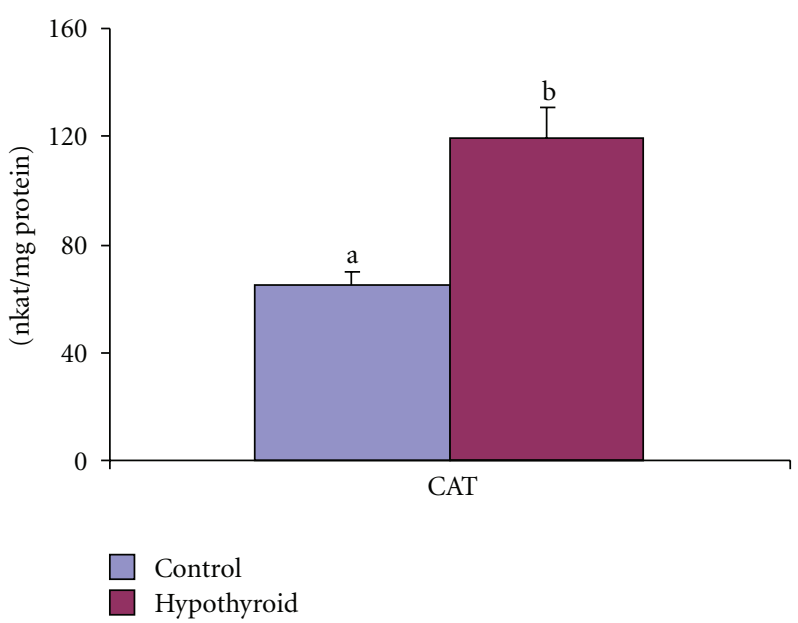

FIGURE 6: Effect of neonatal PTU treatment on catalase activity (CAT; nkat/mg protein) in postmitochondrial fraction (PMF) of testes of rats. Data are expressed as mean \pm S.D. of 5 observations and subjected to unpaired Student's $t$-test. Statistical significance was accepted at $P<0.05$. Control and hypothyroid groups were found to differ significantly at $P<0.05$ as represented by superscripts of different letters. Control (Group-I): 30-day-old control rats; hypothyroid (Group-II): 30-day-old rats with PTU treatment from day 1 postpartum to day 30 postpartum.

to be studied. The present study reports the effect of neonatal persistent hypothyroidism induced by PTU treatment on the testicular antioxidant system and spermatogenic function in rats before puberty. The efficacy of the treatment was confirmed by a dip in $\mathrm{T}_{3}$ and $\mathrm{T}_{4}$ levels and a consequent increase in TSH level in serum of neonatal persistent hypothyroid rats. PTU is well known to decrease the conversion of peripheral $\mathrm{T}_{4}$ to $\mathrm{T}_{3}$ and thereby reduces serum $\mathrm{T}_{3}$ concentration. A significant reduction in the body weight was observed in PTU-treated rats when compared to control rats as reported earlier in case of neonatal hypothyroidism [46].

The lower $\mathrm{H}_{2} \mathrm{O}_{2}$ contents in hypothyroid rats might be due to lower superoxide production in hypothyroid state due to hypometabolic rate. The hypothyroid rat testis resulted in a reduction in lipid peroxidation, which might be as a result of metabolic depression due to hypothyroid condition which serves as a protective factor to prevent lipid peroxidation [ 18 , 47, 48]. In another study, Mogulkoc et al. (2005) [49] also observed a low lipid peroxide content in testicular and renal tissues of hypothyroid rats.

On the contrary, oxidative stress is marked as the increase in protein carbonyl contents in crude and mitochondrial fraction of hypothyroid rat testis in the present study. It is in good agreement with Choudhury et al. (2003) [18] and Sahoo et al. (2008) [7], who observed an increased level of carbonylation of protein in crude homogenate of testes of hypothyroid rats.

Superoxide dismutase (SOD; EC 1.15.1.1) constitutes the first line of coordinated enzymatic defense against ROS by dismutating $\mathrm{O}_{2}{ }^{--}$into $\mathrm{O}_{2}$ and $\mathrm{H}_{2} \mathrm{O}_{2}$. Catalase (CAT; EC 1.11.1.6) and glutathione peroxidase (GPx; EC 1.11.1.9) are most crucial for detoxifying $\mathrm{H}_{2} \mathrm{O}_{2}$, thereby preventing 


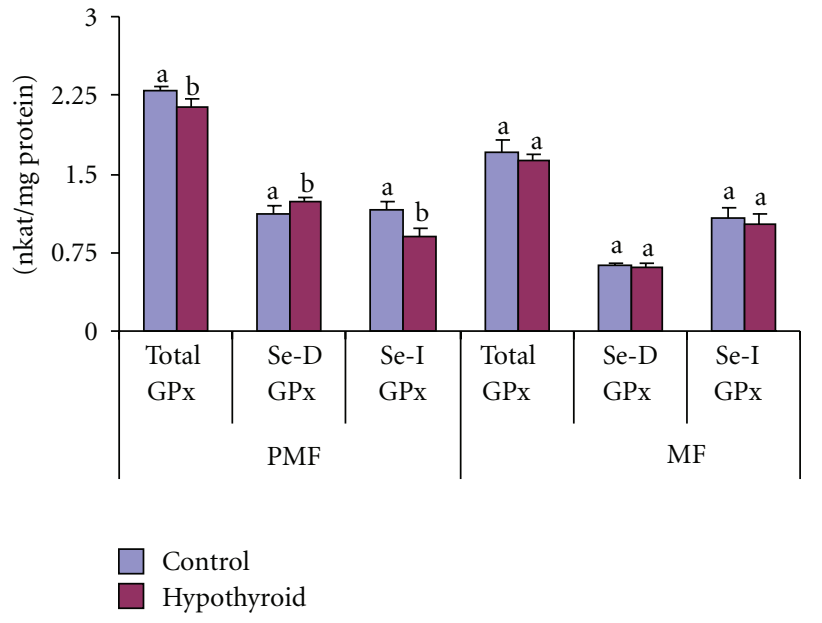

FIgURE 7: Effect of neonatal PTU treatment on glutathione peroxidase activity (GPx; nkat/mg protein) in postmitochondrial fraction (PMF) and mitochondrial fraction (MF) of testes of rats. Data are expressed as mean \pm S.D. of 5 observations and subjected to unpaired Student's $t$-test. Statistical significance was accepted at $P<$ 0.05 . Control and hypothyroid groups were found to differ significantly at $P<0.05$ as represented by superscripts of different letters. Control (Group-I): 30-day-old control rats; hypothyroid (GroupII): 30-day-old rats with PTU treatment from day 1 postpartum to day 30 postpartum.

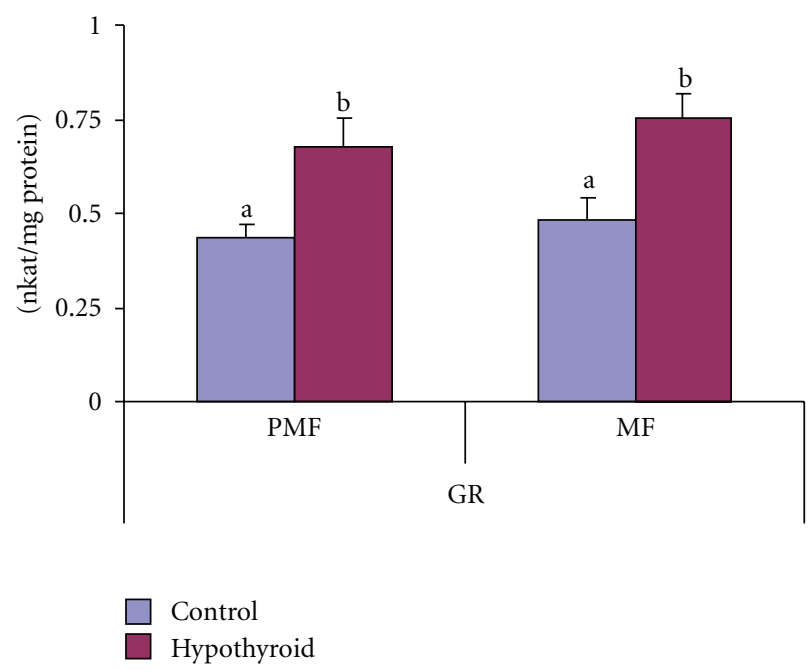

FIGURE 8: Effect of neonatal PTU treatment on glutathione reductase activity (GR; nkat/mg protein) in postmitochondrial fraction (PMF) and mitochondrial fraction (MF) of testes of rats. Data are expressed as mean \pm S.D. of 5 observations and subjected to unpaired Student's $t$-test. Statistical significance was accepted at $P<0.05$. Control and hypothyroid groups were found to differ significantly at $P<0.05$ as represented by superscripts of different letters. Control (Group-I): 30-day-old control rats; hypothyroid (Group-II): 30-day-old rats with PTU treatment from day 1 postpartum to day 30 postpartum.

the generation of hydroxyl radical by the Fenton reaction. Selenium-dependent glutathione peroxidases (Se-D GPxs)

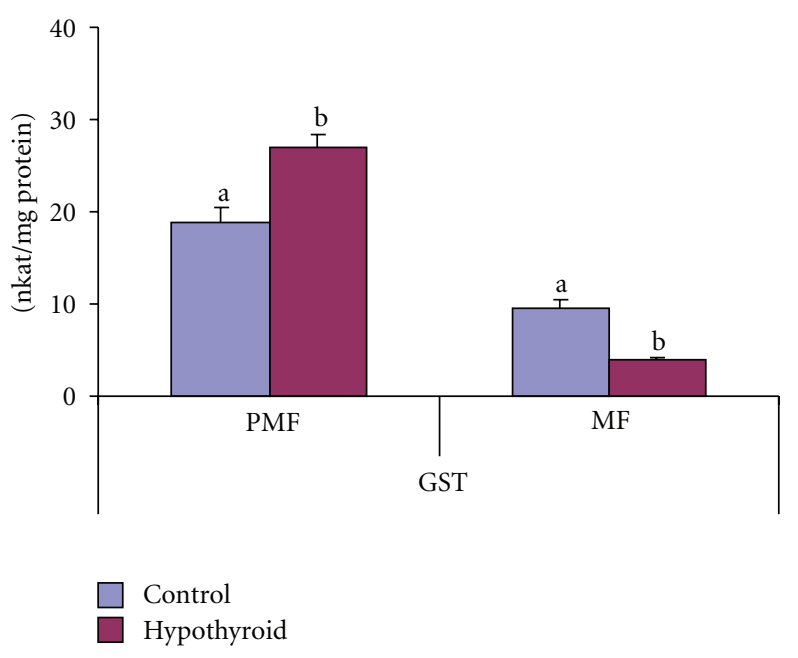

FIGURE 9: Effect of neonatal PTU treatment on glutathione Stransferase activity (GST; nkat/mg protein) in postmitochondrial fraction (PMF) and mitochondrial fraction (MF) of testes of rats. Data are expressed as mean \pm S.D. of 5 observations and subjected to unpaired Student's $t$-test. Statistical significance was accepted at $P<0.05$. Control and hypothyroid groups were found to differ significantly at $P<0.05$ as represented by superscripts of different letters. Control (Group-I): 30-day-old control rats; hypothyroid (Group-II): 30-day-old rats with PTU treatment from day 1 postpartum to day 30 postpartum.

are the major selenoprotein-containing gene family in mammals [50]. Among the different types of selenium-dependent hydroperoxide-reducing isozymes, phospholipid hydroperoxide glutathione peroxidase (PH-GPx/GPx-4; EC 1.11.1.12) and classic cellular glutathione peroxidase (cGPX/GPx-1; EC 1.11.1.9) are primarily found in testis $[19,44,51]$. Seleniumdependent glutathione peroxidases contribute to a part of the total GPx activity. Other GPx activities in mammalian systems are selenium independent [52]. The Se-independent GPx (Se-I GPx), component of GST alfa class (accession: IPR003080 GST_alpha), is responsible for GPx activity in testis [53]. A significant elevation in total SOD and CAT activities in response to neonatal persistent hypothyroidism and a simultaneous decrease in total GPx, Se-D GPx (GPx-1 and GPx-4), and Se-I GPx in the PMF of testis in experimental group suggested that SOD and CAT have predominant role to fight oxidative stress than GPx in hypothyroid rats. The majority of the cytosolic GPx in rat testis existed as selenium- and nonselenium-dependent GPx which is present in the Leydig cells. Much lower levels are associated in sertoli and spermatogenetic cells [54]. GPx is primarily responsible for $\mathrm{H}_{2} \mathrm{O}_{2}$ removal in testicular mitochondria that does not contain catalase. GPx plays a crucial role in scavenging peroxyl radicals and thereby maintains functional integrity of the cell membrane, spermatogenesis, sperm morphology, and motility [55]. In testis, PH-GPx or GPx-4 which is partially cytosolic and partially bound to nuclei and mitochondria is localized within maturating spermatogenetic cells [54]. Gpx-1 has mitochondrial and cytosolic subcellular localizations in all mammalian tissues [56]. We observed that 


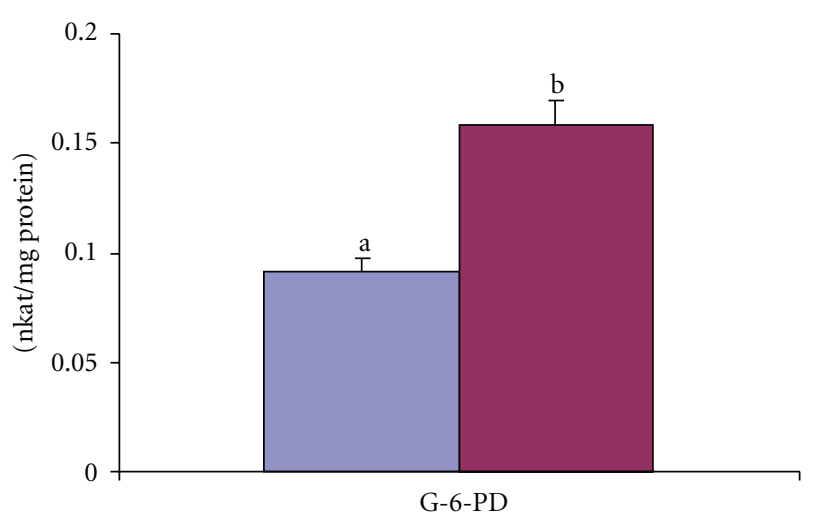

$\square$ Control

FIGURE 10: Effect of neonatal PTU treatment on Glucose-6phosphate dehydrogenase activity (nkat/mg protein) in postmitochondrial fraction (PMF) of testes of rats. Data are expressed as mean \pm S.D. of 5 observations and subjected to unpaired Student's $t$-test. Statistical significance was accepted at $P<0.05$. Control and hypothyroid groups were found to differ significantly at $P<0.05$ as represented by superscripts of different letters. Control (GroupI): 30-day-old control rats; hypothyroid (Group-II): 30-day-old rats with PTU treatment from day 1 postpartum to day 30 postpartum.

mitochondrial Se-dependent GPx (including GPx1 and GPx4) activity was unaltered in hypothyroid rats as reported earlier by Chattopadhyay et al. (2010) [19]. In fact, the role of $\mathrm{cGPx} / \mathrm{GPx} 1$ in protecting testes from oxidative injury is questionable as cGPx knockout mice were found to be fertile [57]. It has also been suggested that the metabolic pathway of testosterone biosynthesis requires protection against peroxidation and will be affected by a decrease in the GPx activity [58]. The lower serum testosterone level in hypothyroid rats in the present study also corroborates the fact.

The decreased GSH level hypothyroid rat testis was recorded in the present study. Mammalian testis contains relatively high levels of GSH [55], which is reported to play an important role in the proliferation and differentiation of spermatogenic cells [59] by protecting them from noxious effects of ROS [60]. The level of GSH is different in testicular cell types, having maximum level in Sertoli and germ cells [61]. Thyroid hormone is known to play a role in triggering the biosynthesis of GSH [62], therefore under hypothyroid states, it is possible that there may be a fall in GSH levels contributing to susceptibility of the testes to oxidative stress. The ratio of reduced glutathione (GSH) to oxidized glutathione (GSSG) in tissues is also considered as one of the important marker of oxidative stress [63]. The decrease in its ratio and also a decrease in GSH contents in testicular MF of hypothyroid rats suggest severely hindered GSH metabolism. Such type of decreased GSH contents in testis-mitochondria of hypothyroid rats was also reported earlier [19]. Moreover, declined GSH contents in germ cells were reported earlier in case of transient hypothyroid rats [25]. The decreased protein-SH contents in both mitochondrial and postmitochondrial fractions might be due to the response against disturbed testicular redox pool in hypothyroidism. Similar effects on testicular protein-SH during hypothyroidism were reported by Chattopadhyay et al. (2010) [19] .

Glutathione-S-transferase (GST; EC 2.5.1.18) metabolizes xenobiotics by conjugating with GSH. In fact, GSTcatalysed conjugation of GSH with exogenous compounds and endogenous metabolites such as 4-hydroxynonenal is regarded as major cellular defense mechanism against toxicity [64]. The decreased activity of this enzyme in MF of testes in neonatal persistent hypothyroid rats reflects the inability of the testis to counteract oxidative stress by this pathway. Glutathione reductase (GR; EC 1.6.4.2) is the enzyme responsible for maintenance of GSH by reducing GSSG back to GSH. Stimulated GR activity in neonatal hypothyroid rats indicated that mitochondrial metabolism attempted reduction of GSSG to GSH in order to maintain redox status. Such type of GR elevation was also reported in hypothyroid rat testis by Sahoo et al. (2008) [7] and Chattopadhyay et al. (2010) [19]. Increase in activity of glucose-6-phosphate dehydrogenase (G6PD) due to neonatal hypothyroidism might be due to higher demand for NADPH as GR requires this reducing equivalence to generate reduced GSH from GSSG. This fact is corroborated by increased GR activities in testicular postmitochondrial fraction too.

The testis seems to be the most vulnerable during neonatal persistent hypothyroidism as evident from the significantly decreased germ cell count. There were also almost no round spermatids found in the testis of hypothyroid rats. Simorangkir et al. (1997) [65] also showed impairment of spermatogenesis in hypothyroid rats. They reported absence of round spermatids in 30 days hypothyroid testis and the inability of the spermatogenic cells to complete meiosis. Francavilla et al. (1991) [66] also reported an impaired spermatogenesis and increased degeneration of germ cells in testis in response to prolonged hypothyroidism in rats. Increased Sertoli cell number in hypothyroid rats in the present investigation might be due to extended Sertoli cell proliferation as in an earlier report, Van Haaster et al. (1992) [67] and Holsberger and Cooke (2005) [68] demonstrated that neonatal hypothyroidism may increase adult Sertoli cell populations by extending Sertoli cell proliferation.

The serum testosterone levels were significantly reduced in the hypothyroid group. As hypothyroidism causes significant decrease in LH and FSH with a fall in serum testosterone $[69,70]$, this might lead to a disruption of the spermatogenic and steroidogenic processes. Moreover, it has been reported that neonatal hypothyroidism adversely affects Leydig cell proliferation, differentiation, along with impaired steroidogenesis $[71,72]$.

Hampered of testicular function may have their origins in fetal or early life as a result of abnormal development or proliferation of Sertoli cells. A compromised antioxidant defence system marked by increased protein carbonylation, disturbed redox status during neonatal hypothyroidism, might have contributed to poor growth and development of testis by affecting spermatogenesis and steroidogenesis in rats before puberty as indicated by reduced germ cell number, complete absence of round spermatids, decreased seminiferous tubule diameter, and decreased testosterone level. Such type of 
altered testicular physiology by hypothyroidism is reflected in adulthood with hampered fertility as evidenced by reduced total viable germ cells [25] and sperm counts [7].

\section{Acknowledgments}

The authors are very much thankful to Professor G.B.N. Chainy, Head of Departments of Zoology and Biotechnology, Utkal University, for his support, help, and suggestions and also for providing necessary facilities during the experiment. They are grateful to the Indian Council of Medical Research (ICMR), New Delhi, DRS-UGC, and the Department of Biotechnology, Government of India, for financial assistance.

\section{References}

[1] C. D. Turner and J. T. Bagnara, General Endocrinology, W.B. Saunders, Philadelphia, Pa, USA, 1976.

[2] S. P. Porterfield and C. E. Hendrich, "The role of thyroid hormones in prenatal and neonatal neurological developmentcurrent perspectives," Endocrine Reviews, vol. 14, no. 1, pp. 94 106, 1993.

[3] S. B. Barker and H. M. Klitgaard, "Metabolism of tissue excised from thyroxine injected rats," The American Journal of Physiology, vol. 170, pp. 81-86, 1952.

[4] A. R. Chowdhury, A. K. Gautam, and B. B. Chatterjee, "Thyroid-testis interrelationship during the development and sexual maturity of the rat," Archives of Andrology, vol. 13, no. 2-3, pp. 233-239, 1984.

[5] R. R. M. Maran, "Thyroid hormones: their role in testicular steroidogenesis," Archives of Andrology, vol. 49, no. 5, pp. 375$388,2003$.

[6] P. S. Cooke and E. Meisami, "Early hypothyroidism in rats causes increased adult testis and reproductive organ size but does not change testosterone levels," Endocrinology, vol. 129, no. 1, pp. 237-243, 1991.

[7] D. K. Sahoo, A. Roy, S. Bhanja, and G. B. N. Chainy, "Hypothyroidism impairs antioxidant defence system and testicular physiology during development and maturation," General and Comparative Endocrinology, vol. 156, no. 1, pp. 63-70, 2008.

[8] E. A. Jannini, S. Ulisse, and M. D'Armiento, "Thyroid hormone and male gonadal function," Endocrine Reviews, vol. 16, no. 4, pp. 443-459, 1995.

[9] S. Palmero, P. Trucchi, M. Prati, E. Fugassa, A. Lanni, and F. Goglia, "Effect of thyroid status on the oxidative capacity of Sertoli cells isolated from immature rat testis," European Journal of Endocrinology, vol. 130, no. 3, pp. 308-312, 1994.

[10] D. K. Sahoo and G. B. N. Chainy, "Tissue specific response of antioxidant defence systems of rat to experimentally-induced hyperthyroidism," National Academy Science Letters, vol. 30, no. 7-8, pp. 247-250, 2007.

[11] R. Pamplona, M. Portero-Otin, C. Ruiz et al., "Thyroid status modulates glycoxidative and lipoxidative modification of tissue proteins," Free Radical Biology and Medicine, vol. 27, no. 7-8, pp. 901-910, 1999.

[12] J. J. Staub, B. U. Althaus, H. Engler et al., "Spectrum of subclinical and overt hypothyroidism, effect of thyrotropin, prolactin and thyroid reserve and metabolic impact on peripheral target tissues," The American Journal of Medicine, vol. 92, pp. 355-362, 1992.
[13] R. D. Utiger, P. Felis, J. D. Baxter, and L. A. Frohman, “Thyroid disease," in Endocrinology and Metabolism, pp. 435-519, McGraw Hill, New York, NY, USA, 3rd edition, 1995.

[14] L. Tahmaz, A. Gokalp, Y. Kibar et al., "Effect of hypothyroidism on the testes in mature rats and treatment with levothyroxine and zinc," Andrologia, vol. 32, no. 2, pp. 85-89, 2000.

[15] E. Meisami, A. Najafi, and P. S. Timiras, "Enhancement of seminiferous tubular growth and spermatogenesis in testes of rats recovering from early hypothyroidism: a quantitative study," Cell and Tissue Research, vol. 275, no. 3, pp. 503-511, 1994.

[16] J. N. Rao, J. Y. Liang, P. Chakraborti, and P. Feng, "Effect of thyroid hormone on the development and gene expression of hormone receptors in rat testis in vivo," Journal of Endocrinological Investigation, vol. 26, no. 5, pp. 435-443, 2003.

[17] R. M. Sharpe, C. McKinnell, C. Kivlin, and J. S. Fisher, "Proliferation and functional maturation of Sertoli cells, and their relevance to disorders of testis function in adulthood," Reproduction, vol. 125, no. 6, pp. 769-784, 2003.

[18] S. Choudhury, G. B. N. Chainy, and M. M. Mishro, "Experimentally induced hypo- and hyper-thyroidism influence on the antioxidant defence system in adult rat testis," Andrologia, vol. 35, no. 3, pp. 131-140, 2003.

[19] S. Chattopadhyay, S. Choudhury, A. Roy, G. B. N. Chainy, and L. Samanta, "T3 fails to restore mitochondrial thiol redox status altered by experimental hypothyroidism in rat testis," General and Comparative Endocrinology, vol. 169, no. 1, pp. 39-47, 2010.

[20] Y. Clermont and B. Perey, "Quantitative study of the cell population of the seminiferous tubules in immature rats," The American Journal of Anatomy, vol. 100, no. 2, pp. 241-267, 1957.

[21] O. P. F. Clausen, K. Purvis, and V. Hansson, "Endocrine correlates of meiosis in the male rat," Archives of Andrology, vol. 2, no. 1, pp. 59-66, 1979.

[22] E. C. Roosen-Runge and D. Anderson, "The development of the interstitial cells in the testis of the albino rat," Acta Anatomica, vol. 37, pp. 125-137, 1959.

[23] J. Tapanainen, T. Kuopio, L. J. Pelliniemi, and I. Huhtaniemi, "Rat testicular endogenous steroids and number of Leydig cells between the fetal period and sexual maturity," Biology of Reproduction, vol. 31, no. 5, pp. 1027-1035, 1984.

[24] J. M. Orth, "Proliferation of Sertoli cells in fetal and postnatal rats: a quantitative autoradiographic study," Anatomical Record, vol. 203, no. 4, pp. 485-492, 1982.

[25] D. K. Sahoo, A. Roy, and G. B. N. Chainy, "PTU-induced neonatal hypothyroidism modulates antioxidative status and population of rat testicular germ cells," National Academy Science Letters, vol. 29, no. 3-4, pp. 133-135, 2006.

[26] O. H. Lowry, N. J. Rosebrough, A. L. Farr, and R. J. Randall, "Protein measurement with the Folin phenol reagent," The Journal of Biological Chemistry, vol. 193, no. 1, pp. 265-275, 1951.

[27] H. Ohkawa, N. Ohishi, and K. Yagi, "Assay for lipid peroxides in animal tissues by thiobarbituric acid reaction," Analytical Biochemistry, vol. 95, no. 2, pp. 351-358, 1979.

[28] R. L. Levine, D. Garland, C. N. Oliver et al., "Determination of carbonyl content in oxidatively modified proteins," Methods in Enzymology, vol. 186, pp. 464-478, 1990.

[29] J. Sedlak and R. H. Lindsay, "Estimation of total, proteinbound, and nonprotein sulfhydryl groups in tissue with Ellman's reagent," Analytical Biochemistry, vol. 25, no. C, pp. 192205, 1968. 
[30] J. Wudarczyk, G. Debska, and E. Lenartowicz, "Relation between the activities reducing disulfides and the protection against membrane permeability transition in rat liver mitochondria," Archives of Biochemistry and Biophysics, vol. 327, no. 2, pp. 215-221, 1996.

[31] F. Tietze, "Enzymic method for quantitative determination of nanogram amounts of total and oxidized glutathione: applications to mammalian blood and other tissues," Analytical Biochemistry, vol. 27, no. 3, pp. 502-522, 1969.

[32] O. W. Griffith, "Determination of glutathione and glutathione disulfide using glutathione reductase and 2-vinylpyridine," Analytical Biochemistry, vol. 106, no. 1, pp. 207-212, 1980.

[33] E. Pick and Y. Keisari, "Superoxide anion and hydrogen peroxide production by chemically elicited peritoneal macrophagesinduction by multiple nonphagocytic stimuli," Cellular Immunology, vol. 59, no. 2, pp. 301-318, 1981.

[34] G. Cohen, D. Dembiec, and J. Marcus, "Measurement of catalase activity in tissue extracts," Analytical Biochemistry, vol. 34, no. 1, pp. 30-38, 1970.

[35] K. Das, L. Samanta, and G. B. N. Chainy, "A modified spectrophotometric assay of superoxide dismutase using nitrite formation by superoxide radicals," Indian Journal of Biochemistry and Biophysics, vol. 37, no. 3, pp. 201-204, 2000.

[36] D. E. Paglia and W. N. Valentine, "Studies on the quantitative and qualitative characterization of erythrocyte glutathione peroxidase," The Journal of Laboratory and Clinical Medicine, vol. 70, no. 1, pp. 158-169, 1967.

[37] F. Carmagnol, P. M. Sinet, and H. Jerome, "Selenium-dependent and non-selenium-dependent glutathione peroxidases in human tissue extracts," Biochimica et Biophysica Acta, vol. 759, no. 1-2, pp. 49-57, 1983.

[38] V. Massey and C. H. Williams, "On the reaction mechanism of yeast glutathione reductase," Journal of Biological Chemistry, vol. 240, no. 11, pp. 4470-4480, 1965.

[39] W. H. Habig, M. J. Pabst, and W. B. Jakoby, "Glutathione-Stransferases," The Journal of Biological Chemistry, vol. 249, pp. 713-739, 1974.

[40] C. Y. Lee, "Glucose-6-phosphate dehydrogenase from mouse," Methods in Enzymology, vol. 89, no. C, pp. 252-257, 1982.

[41] M. S. Christian and N. A. Trenton, "Evaluation of thyroid function in neonatal and adult rats: the neglected endocrine mode of action," Pure and Applied Chemistry, vol. 75, no. 1112, pp. 2055-2068, 2003.

[42] L. B. Valle, R. M. Oliveira-Filho, J. H. Romaldini, and P. F. Lara, "Pituitary-testicular axis abnormalities in immature male hypothyroid rats," Journal of Steroid Biochemistry, vol. 23, no. 3, pp. 253-257, 1985.

[43] D. K. Sahoo, A. Roy, S. Bhanja, and G. B. N. Chainy, "Experimental hyperthyroidism-induced oxidative stress and impairment of antioxidant defence system in rat testis," Indian Journal of Experimental Biology, vol. 43, no. 11, pp. 1058-1067, 2005.

[44] D. K. Sahoo, A. Roy, S. Chattopadhyay, and G. B. N. Chainy, "Effect of $\mathrm{T}_{3}$ treatment on glutathione redox pool and its metabolizing enzymes in mitochondrial and post-mitochondrial fractions of adult rat testes," The Indian Journal of Experimental Biology, vol. 45, no. 4, pp. 338-346, 2007.

[45] D. K. Sahoo, A. Roy, and G. B. N. Chainy, "Protective effects of vitamin $\mathrm{E}$ and curcumin on L-thyroxine-induced rat testicular oxidative stress," Chemico-Biological Interactions, vol. 176, no. 2-3, pp. 121-128, 2008.

[46] R. R. Maran, R. Sivakumar, J. Arunakaran et al., "Durationdependent effect of transient neonatal hypothyroidism on Sertoli and germ cell number, and plasma and testicular interstitial fluid androgen binding protein concentration," Endocrine Research, vol. 25, no. 3-4, pp. 323-340, 1999.

[47] A. Swaroop and T. Ramasarma, "Heat exposure and hypothyroid conditions decrease hydrogen peroxide generation in liver mitochondria," Biochemical Journal, vol. 226, no. 2, pp. 403408, 1985.

[48] K. Asayama, K. Dobashi, H. Hayashibe, Y. Megata, and K. Kato, "Lipid peroxidation and free radical scavengers in thyroid dysfunction in the rat: a possible mechanism of injury to heart and skeletal muscle in hyperthyroidism," Endocrinology, vol. 121, no. 6, pp. 2112-2118, 1987.

[49] R. Mogulkoc, A. K. Baltaci, E. Oztekin, A. Ozturk, and A. Sivrikaya, "Short term thyroxine administration leads to lipid peroxidation in renal and testicular tissues of rats with hypothyroidism," Acta Biologica Hungarica, vol. 56, no. 3-4, pp. 225-232, 2005.

[50] R. S. Esworthy, R. Aranda, M. G. Martín, J. H. Binder, S. W. Doroshow, and F. F. Chu, "Mice with combined disruption of Gpx1 and Gpx2 genes have colitis," The American Journal of Physiology, vol. 281, no. 3, pp. G848-G855, 2001.

[51] A. Zini and P. N. Schlegel, "Expression of glutathione peroxidases in the adult male rat reproductive tract," Fertility and Sterility, vol. 68, no. 4, pp. 689-695, 1997.

[52] P. Doyen, P. Vasseur, and F. Rodius, "Identification, sequencing and expression of selenium-dependent glutathione peroxidase transcript in the freshwater bivalve Unio tumidus exposed to Aroclor 1254," Comparative Biochemistry and Physiology, Part C, vol. 144, no. 2, pp. 122-129, 2006.

[53] E. Institoris, H. Eid, I. Bodrogi, and M. Bak, "Glutathione related enzymes in human testicular germ cell tumors and normal testes," Anticancer Research, vol. 15, no. 4, pp. 13711374, 1995.

[54] K. Mehrotra, R. Morgenstern, M. Bengtsson Ahlberg, and A. Georgellis, "Hypophysectomy and/or peroxisome proliferators strongly influence the levels of phase II xenobiotic metabolizing enzymes in rat testis," Chemico-Biological Interactions, vol. 122, no. 2, pp. 73-87, 1999.

[55] H. I. Calvin and S. I. Turner, "High levels of glutathione attained during postnatal development of rat testis," Journal of Experimental Zoology, vol. 219, no. 3, pp. 389-393, 1982.

[56] R. S. Esworthy, Y. S. Ho, and F. F. Chu, "The Gpxl gene encodes mitochondrial glutathione peroxidase in the mouse liver," Archives of Biochemistry and Biophysics, vol. 340, no. 1, pp. 59-63, 1997.

[57] J. B. De Haan, C. Bladier, P. Griffiths et al., "Mice with a homozygous null mutation for the most abundant glutathione peroxidase,GPx 1, show increased susceptibility to the oxidative stress-inducing agents paraquat and hydrogen peroxide," Journal of Biological Chemistry, vol. 273, no. 35, pp. 2252822536, 1998.

[58] R. Chandra, R. Aneja, C. Rewal, R. Konduri, S. K. Dass, and S. Agarwal, "An opium alkaloid-papaverine ameliorates ethanolinduced hepatotoxicity: diminution of oxidative stress," Indian Journal of Clinical Biochemistry, vol. 15, no. 2, pp. 155-160, 2000.

[59] M. F. Knapen, P. L. Zusterzeel, W. H. Peters, and E. A. Steegers, "Glutathione and glutathione-related enzymes in reproduction: a review," European Journal of Obstetrics Gynecology and Reproductive Biology, vol. 82, no. 2, pp. 171-184, 1999.

[60] C. M. Teaf, R. D. Harbison, and J. B. Bishop, "Germ-cell mutagenesis and GSH depression in reproductive tissue of the F-344 rat induced by ethyl methanesulfonate," Mutation Research, vol. 144, no. 2, pp. 93-98, 1985. 
[61] F. Bauché, "Antioxidant system in rat testicular cells," FEBS Letters, vol. 349, no. 3, pp. 392-396, 1994.

[62] V. Fernández and L. A. Videla, "Hepatic glutathione biosynthetic capacity in hyperthyroid rats," Toxicology Letters, vol. 89, no. 2, pp. 85-89, 1996.

[63] H. Sies, "Glutathione and its role in cellular functions," Free Radical Biology and Medicine, vol. 27, no. 9-10, pp. 916-921, 1999.

[64] J. Z. Cheng, S. S. Singhal, A. Sharma et al., "Transfection of mGSTA4-4 in HL-60 cells protects against 4-hydroxynonenalinduced apoptosis by inhibiting JNK-mediated signaling," Archives of Biochemistry and Biophysics, vol. 392, no. 2, pp. 197-207, 2001.

[65] D. R. Simorangkir, N. G. Wreford, and D. M. De Kretser, "Impaired germ cell development in the testes of immature rats with neonatal hypothyroidism," Journal of Andrology, vol. 18, no. 2, pp. 186-193, 1997.

[66] S. Francavilla, G. Cordeschi, G. Properzi et al., "Effect of thyroid hormone on the pre- and post-natal development of the rat testis," Journal of Endocrinology, vol. 129, no. 1, pp. 3542, 1991.

[67] L. H. Van Haaster, F. H. De Jong, R. Docter, and D. G. De Rooij, "The effect of hypothyroidism on Sertoli cell proliferation and differentiation and hormone levels during testicular development in the rat," Endocrinology, vol. 131, no. 3, pp. 1574-1576, 1992.

[68] D. R. Holsberger and P. S. Cooke, "Understanding the role of thyroid hormone in Sertoli cell development: a mechanistic hypothesis," Cell and Tissue Research, vol. 322, no. 1, pp. 133140, 2005.

[69] J. D. Kirby, A. E. Jetton, P. S. Cooke et al., "Developmental hormonal profiles accompanying the neonatal hypothyroidism induced increase in adult testicular size and sperm production in the rat," Endocrinology, vol. 131, no. 2, pp. 559-565, 1992.

[70] M. P. Hardy, J. D. Kirby, R. A. Hess, and P. S. Cooke, "Leydig cells increase their numbers but decline in steroidogenic function in the adult rat after neonatal hypothyroidism," Endocrinology, vol. 132, no. 6, pp. 2417-2420, 1993.

[71] S. M. L. C. Mendis-Handagama, H. B. Ariyaratne, K. R. Teunissen Van Manen, and R. L. Haupt, "Differentiation of adult Leydig cells in the neonatal rat testis is arrested by hypothyroidism," Biology of Reproduction, vol. 59, no. 2, pp. 351-357, 1998.

[72] R. R. Maran, K. Ravichandran, J. Arunakaran, and M. M. Aruldhas, "Impact of neonatal hypothyroidism on Leydig cell number, plasma, and testicular interstitial fluid sex steroids concentration," Endocrine Research, vol. 27, no. 1-2, pp. 119141,2001 . 


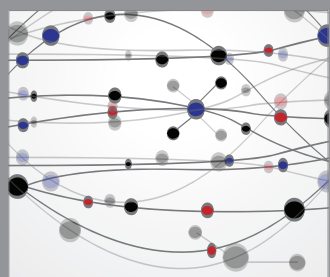

The Scientific World Journal
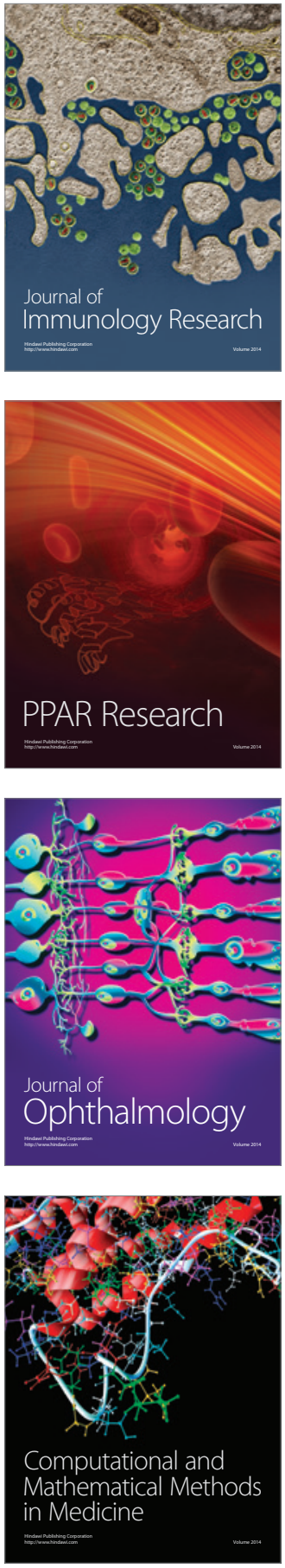

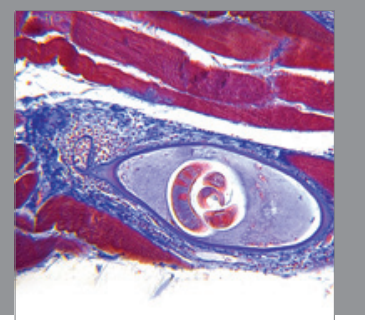

Gastroenterology

Research and Practice
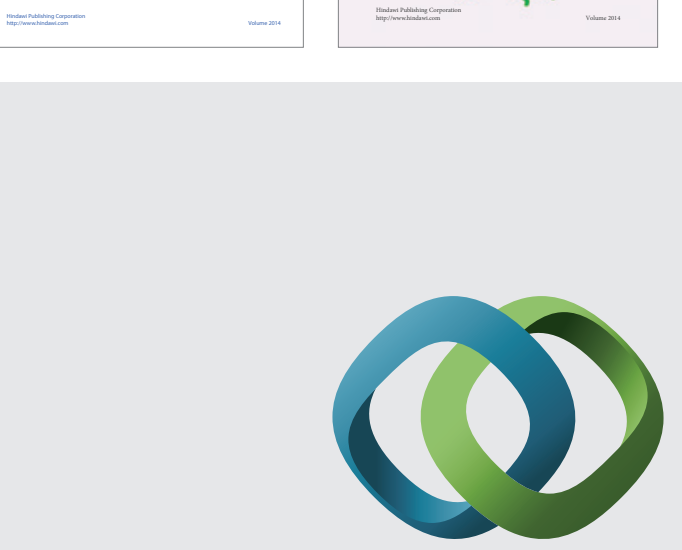

\section{Hindawi}

Submit your manuscripts at

http://www.hindawi.com
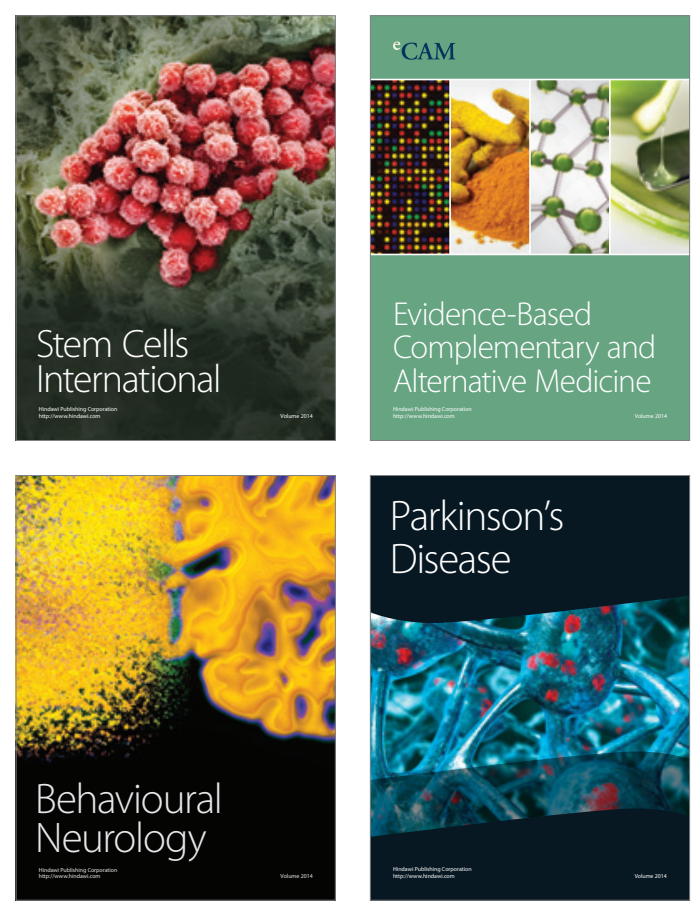

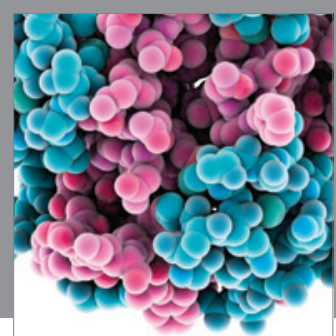

Journal of
Diabetes Research

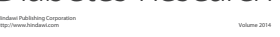

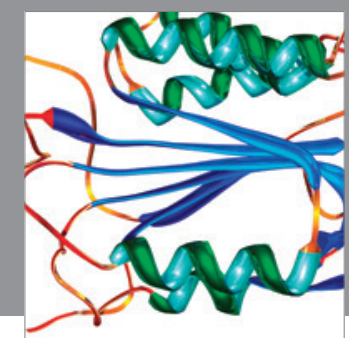

Disease Markers
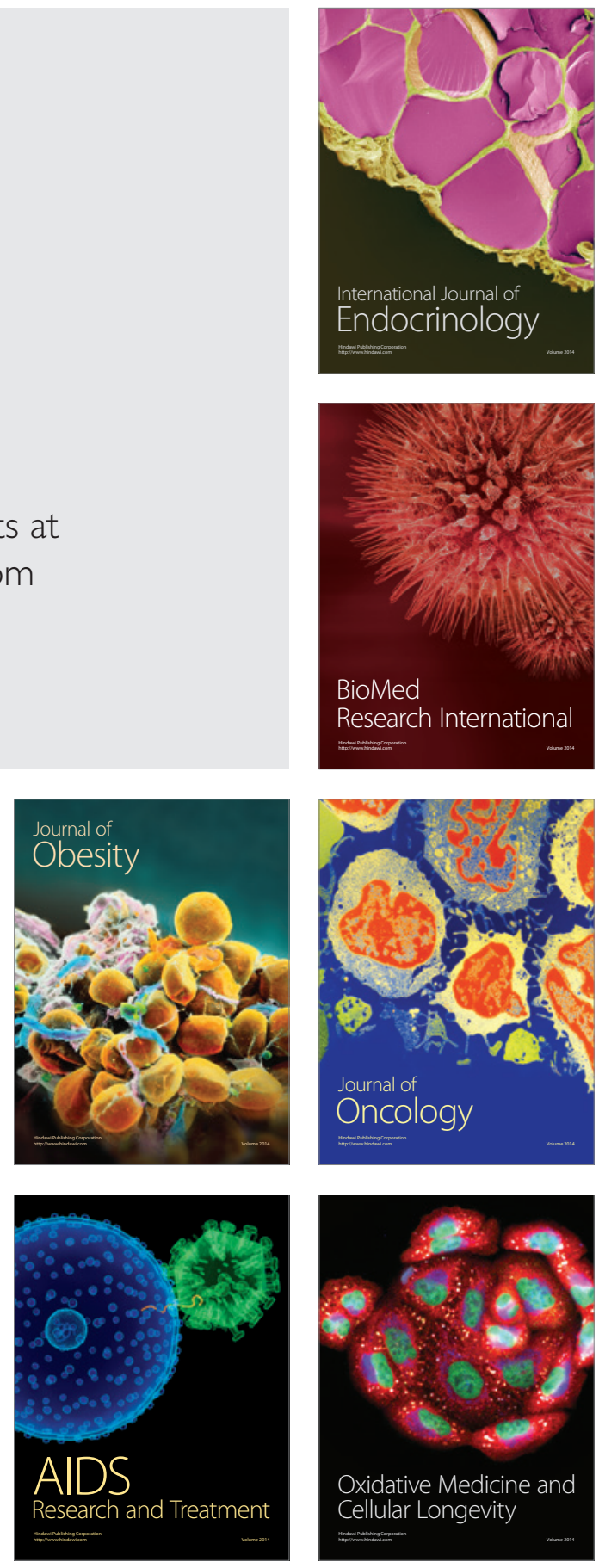